\title{
PEMIKIRAN TOKOH PENDIDIKAN DALAM BUKU LIFELONG LEARNING: POLICIES, PRACTICES, AND PROGRAMS (Perspektif Peningkatan Mutu Pendidikan di Indonesia)
}

\author{
Oleh \\ I Ketut Sudarsana \\ Tenaga Pendidik pada Pascasarjana IHDN Denpasar
}

\begin{abstract}
The substances of the views of the some figures depicted in the Lifelong Learning Policies, Practices, And Programs, especially the ones found on Chapter 11 to 15 mostly describe the relation between the school education, families, and society. They are in accordance with the Indonesian Government Regulation No20/2003 on the national system of Indonesian education that regulate its informal, formal and nonformal sectors. The least attended nonformal one has actually equal charge, namely providing the best education to the society.
\end{abstract}

Keywords: Education Figures, Developing Education Quality

\section{PENDAHULUAN}

Pembangunan pendidikan nasional adalah suatu usaha yang bertujuan untuk mewujudkan masyarakat Indonesia yang berkualitas, maju, mandiri, dan modern. Pembangunan pendidikan merupakan bagian penting dari upaya membangun karakter secara menyeluruh dan sungguh-sungguh untuk meningkatkan harkat dan martabat bangsa. Keberhasilan pendidikan dalam membangun karakter manusia diperlukan pendidikan yang akurat karena pendidikan akan memberikan kontribusi besar pada pencapaian tujuan pembangunan nasional secara keseluruhan. Dewasa ini, pembangunan dan pembinaan karakter suatu bangsa menjadi suatu istilah yang semakin sering diungkapkan namun diperlukan pemahaman yang lebih baik, khususnya dalam menjadikan pembangunan fisik suatu bangsa sebagai salah satu instrumen dalam pembinaan karakter manusia.

Secara empirik pendidikan di Indonesia mengalami degradasi pemaknaan nilai-nilai pendidikan. Ketika komersialisasi dalam dunia pendidikan semakin merajalela, ketika pendidikan bukan menjadi milik semua orang, dan ketika pendidikan terbaik hanya bisa dinikmati oleh orang-orang yang memiliki kelebihan uang. Dampak terbesar yang dirasakan adalah, ketika materialisme seolah menjadi tujuan hidup.

Perlu ada sebuah terobosan dalam dunia pendidikan di Indonesia, yang mampu memberikan pencerahan bagi peserta didik. Pendidikan yang lebih terbuka, terarah dan tidak hanya membahas soal teknis keilmuan semata, namun suatu pendidikan yang mampu memberikan rangsangan inspiratif bagi terjadinya perubahan karakter peserta didik. Layanan pendidikan alternatif yang diprogramkan di luar sistem persekolahan tersebut bisa berfungsi sebagai pengganti, penambah, dan atau pelengkap pendidikan formal sistem persekolahan.

Secara garis besar Judith Champan dan David Aspin menguraikan tentang peran sekolah dalam mewujudkan belajar sepanjang 
hayat. Hal tersebut dilakukan melalui pengembangan kerjasama antara sekolah dengan lembaga keluarga, lembaga bisnis, lembaga lain dalam masyarakat dan dengan masyarakat sendiri. Di samping itu sekolah juga memiliki peran sendiri. Dalam kaitannya dengan belajar sepanjang hayat, wajib belajar harus ditujukan pada provisi berbasis pengetahuan, dan pengembangan meta-skill untuk belajar. Oleh karena itu wajib belajar harus dapat memberikan pengatahuan umum untuk pengembangan kemampuan kognitif, afektif dan pemerolehan keterampilan belajar yang diperlukan untuk belajar sepanjang hayat.

Albert H. Yee dan Joseph Y.S. Cheng mengupas tentang fenomena belajar sepanjang hayat yang terjadi di Amerika dan Hongkong. Aspek psikologis dan kultural dijadikan pijakan dalam analisisnya. Kedua faktor tersebut dipandang sebagai bagian yang tidak terpisahkan dari proses belajar sepanjang hayat. Proses pertumbuhan dan pengasuhan berkait dengan perkembangan manusia, dan hal tersebut terjadi dalam dan dipengaruhi oleh lingkungan sosial budaya.

Menurut Yukiko Sawono, Belajar sepanjang hayat telah mengalami perkembangan yang sangat signifikan. Jika pada masa sebelumnya, belajar dimaknai secara sempit pada pendidikan waktu luang, dan hobi, sekarang dipandang sebagai satu proses pendidikan untuk semua aspek pendidikan. Perhatian terhadap penerapan prinsip ini pun semakin nyata. Hal ini dapat dilihat dari berbagai kebijakan dan implementasi pembaharuan pendidikan.

Grace O.M.Lee memaparkan tentang perkembangan belajar sepanjang hayat di Hongkong, dan peran apa yang harus dilakukan untuk dapat meningkatkan kegiatan belajar tersebut.

Brian Rice dan John Steckely menguraikan bahwa Setiap masyarakat berusaha untuk mempertahankan kebudayaannya, tidak terkecuali penduduk asli di Canada. Proses pelestarian budaya tersebut dilakukan melalui belajar. Dalam masyarakat penduduk asli Canada, proses belajar tersebut dilakukan melalui dua cara, yaitu : a). Ceritera. Dalam hal ini orang tua (elders) memegang peran yang sangat penting. Melalui cerita ini mereka menyampaikan berbagai pengetahuan yang menjadi dasar identitas budayanya pada semua anggota masyarakat. Para orang tua akan melakukan kunjungan dari satu desa ke desa yang lainnya. Di samping itu, masyarakat juga saling berkunjung untuk berceritera, mengajar upacara dan peran yang dibutuhkan oleh anggota masyarakat dengan maksud untuk mempertahankan budaya mereka. b). Upacara ritual. Cara ini dilakukan secara lebih formal dalam satu acara ritual keagamaan yang khidmat.

\section{PEMBAHASAN}

\subsection{Pemikiran Tokoh Pendidikan dalam Buku Lifelong Learning: Policies, Practices, And Programs}

\subsubsection{Sekolah sebagai Pusat Belajar} Sepanjang Hayat (Oleh: Judith Champan dan David Aspin)

Peran sekolah dalam mewujudkan belajar sepanjang hayat dilakukan melalui pengembangan kerjasama antara sekolah dengan lembaga keluarga, lembaga bisnis, lembaga lain dalam masyarakat dan dengan masyarakat sendiri. Di samping itu sekolah juga memiliki peranan sendiri. Dalam kaitannya dengan belajar sepanjang hayat, wajib belajar harus ditujukan pada provisi berbasis pengetahuan, dan pengembangan meta-skill untuk belajar. Oleh karena itu wajib belajar harus dapat memberikan pengatahuan umum untuk pengembangan kemampuan kognitif, afektif dan pemerolehan keterampilan belajar yang diperlukan untuk belajar sepanjang hayat.

Sementara itu lembaga keluarga dapat berfungsi sebagai sumber dukungan dan stimulus untuk meningkatkan pemahaman makna dan nilai belajar sepanjang hayat. 
Sebagai contoh : mengembangkan harapan tinggi pada anak, impian masa depan, penghargaan terhadap kerja keras sebagai kunci keberhasilan, persepsi sebagai lembaga penyelesaian masalah, ketaatan pada aturan rumah tangga, menjalin komunikasi dengan sekolah. Di samping itu, sekolah dapat menumbuhkan kesempatan belajar sepanjang hayat melalui kerjasama dengan keluarga.

Hal lain yang dipandang penting untuk dikembangkan adalah kerjasama dengan dunia bisnis. Kerjasama ini dapat dikembangkan pada tingkat pengambilan kebijakan, manajemen sekolah, pelatihan bagi para guru, pengiriman anak ke lembaga kerja, dan pembelajaran di kelas. Untuk lebih mengoptimalkan perwujudan belajar sepanjang hayat, di samping kerjasama sebagaimana di kemukakan di atas, lembaga sekolah juga perlu membuka diri untuk menjalin kerjasama dengan berbagai potensi budaya masyarakat yang sangat beragam, dan lembaga-lembaga lain yang ada di masyarakat untuk secara bersamasama memberi kesempatan belajar bagi semua peserta didik dan anggota masyarakat.

\subsubsection{Belajar Sepanjang Hayat di Amerika dan Hongkong: Sebelum dan sesudah Tahun 1977 (Oleh: Albert H. Yee dan Joseph Y.S. Cheng)}

Teori perkembangan yang dijadikan dasar analsis Albert H. Yee dan Joseph Y.S. Cheng adalah teori Erikson. Dari delapan tahap perkembangan Erikson, hanya tiga tahap yang digunakan sebagai pijakan untuk menganalisis belajar sepanjang hayat, yaitu tahap awal, adolesen dan masa tua.

Pada tahap awal kemungkinan arah perkembangan yang terjadi adalah percaya vs tidak percaya. Perkembangan ini sangat ditentukan oleh proses belajar dalam keluarga. Pada tahap adolesen, perkembangan individu akan mengarah ke penemuan identitas diri atau kebingungan peran. Pada tahap ini lembaga keluarga dan sekolah memiliki peran penting.
Pola asuh dalam lembaga keluarga, seperti harapan akan karier, kesuksesan, asprasi pendidikan, akan sangat berpengaruh terhadap proses perkembangan tersebut. Dalam hal ini remaja di Hongkong relatif tidak mengalami kesulitan bila dibandingkan dengan remaja Amerika. Di Hongkong, lembaga keluarga memiliki tanggung jawab penuh terhadap masa depan anaknya, oleh karena itu menaruh harapan tinggi terhadap pendidikan anaknya, dan ikut menentukan proses pendidikannya. Sementara itu lembaga sekolah hanya memiliki jalur linier dan tidak banyak memberi pilihan. Beda dengan di Hongkong, lembaga keluarga Amerika lebih memberi kebebasan pada anaknya untuk memilih dan menentukan masa depannya sendiri, dan sistem pendidikannya lebih banyak memberi pilihan pengembangan karier. Pada tahap akhir, perkembangan akan mengarah pada kepuasaan atau kekecewaan diri. Pada tahap ini lembaga keluarga dan masyarakat memiliki peran penting dalam membantu perkembangan individu.

Lebih lanjut penulis mengemukakan bahwa teori perkembangan Erikson ini sangat membantu dalam mengantisipasi dan menyiapkan perkembangan sepanjang rentang kehidupan individu. Dalam aspek kultural, agama Konfucu dipandang memiliki pengaruh yang sangat dalam terhadap perilaku dan pendidikan masyarakat Hongkong. Agama ini memiliki filosofi bahwa kebijaksanaan dan pengetahuan dapat dimiliki oleh semua orang yang mau mencarinya. Oleh karena itu individu harus belajar menjadi manusiawi melalui belajar sepanjang hayat, refleksi, disiplin dan kerendahan hati. Dalam satu tulisan kuno, anonim, seorang ilmuwan Konfucu mengatakan bahwa tujuan dari belajar adalah mengembangkan pengetahuan diri, membantu orang lain mengaktualisasikan diri, dan berjuang untuk keunggulan moral. Pentingnya pendidikan dalam ajaran Konfucu diilustrasikan Konfuscu sebagai seorang guru dengan wajah tegang, membawa tongkat untuk menghardik murid yang malas. 
Di samping memberi ajaran bahwa setiap orang memiliki potensi untuk belajar dan tanggung jawab untuk belajar, serta meningkatkan kehidupan moral sepanjang kehidupan, Konfusius juga menekankan pentinganya kebutuhan pengembangan diri.

Selain itu Konfusius juga menekankan pentingnya pendidikan moral untuk mencapai keharmonisan kehidupan masyarakat. Keluraga sebagai bagian dari sistem sosial masyarakat memiliki peran penting di dalam menanamkan nilai-nilai moral, seperti loyalitas, kepatuhan, kasih sayang, tanggung jawab, persaudaraan. Keluarga besar dan atau inti menjadi kunci dari makrokosmos dari masyarakat. Sampai saat ini nilai dan peran tersebut masih kuat dipegang oleh masyarakat Hongkong.

\subsubsection{Belajar Sepanjang Hayat : Instru- men untuk Meningkatkan Pendidikan Sekolah di Jepang (Oleh: Yukiko Sawono)}

Pada tahun 1990, pemerintah mengeluarkan kebijakan "Development of Mechanisms and Measure for Promotion of Lifelong Learning", yang diantaranya mewajibkan : Pembentukan dewan belajar sepanjang hayat pada tingkat kabupaten, pamong praja, sistem untuk perencanaan , pengembangan, langkah implementasi pada tingkat lokal, rencana pengembangan kerjasama antar lembaga, kriteria yang digunakan untuk melaksanakan kegiatan. Sejalan dengan kebijakan tersebut, dewan nasional untuk belajar sepanjang hayat dibentuk.

Dalam rangka mengimplementasikan belajar sepanjang hayat, pemerintah telah mengembangkan dan melaksanakan program pendidikan sebagai berikut : pendidikan sosial untuk para pemimpin, pengembangan kegiatan voluntir, kegiatan lingkar masyarakat, pendidikan untuk wanita, program ekstensi, pengembangan sistem informasi belajar sepanjang hayat.

Di samping kegiatan yang secara langsung berada dibawah naungan belajar sepanjang hayat, pemerintah juga melakukan modifikasi kurikulum sekolah dasar dan sekolah lanjutan pertama. Modifikasi tersebut dimaksudkan untuk disesuaikan dengan teori dan prinsip belajar sepanjang hayat dalam rangka memasuki abad ke 21. Modifikasi tersebut meliputi : pengembangan peserta secara utuh, penekanan pada peserta didik, pengembangan belajar musyawarah, apresiasi budaya Jepang dan pengembangan saling pengertian.

Selama ini pembelajaran yang digunakan guru lebih menekankan pada pemacuan aspek akademik untuk dapat lolos seleksi masuk jenjang selanjutnya. Hal ini mengakibatkan dimensi kehidupan sosial kemanusian tidak berkembang pada diri peserta didik. Menyadari akan kekurangan tersebut, pemerintah mendorong proses pembelajaran yang memberikan pengalaman kehidupan secara langsung. Salah satu bentuk perhatian tersebut, sejak tahun 1992 pemerintah menerapkan 5 hari sekolah, dengan maksud memberi kesempatan pada anak untuk bersama dengan keluarga dan masyarakat, serta belajar di luar sekolah secara lebih memadai.

Pemendekan waktu belajar ternyata tidak membuahkan hasil sebagaimana yang diharapkan. Di luar jam sekolah ternyata para orang tua mengikutsertakan anaknya kedalam berbagai bentuk bimbingan belajar dan sekolah sore ( cram school /Juku). Untuk siswa SD yang mengikuti bimbingan/les ada $77 \%$, SLP $28 \%$, dan yang masuk sekolah sore, siswa SD $24 \%$ dan SLP $36 \%$. Jumlah tersebut dari waktu ke waktu semakin meningkat. Tetapi sayangnya program tersebut telah membuahkan dampak negatif, seperti kesehatan, meningkatkan persaingan, kehilangan kesempatan bermain, kemampuan berpikir kritis dan minat belajar tidak berkembang. 
Dalam rangka mengatasi masalah tersebut, Dewan Pusat untuk Pendidikan, yang merupakan penasehat kementrian pendidikan mengeluarkan laporan bertajuk : Model untuk Pendidikan Nasional dalam Abad 21 ". Ada dua ide pokok yang diusulkan yaitu semangat untuk hidup ( zest for living ) dan kedamaian pikiran (Peace of mind). Esensi dari dua ide tersebut adalah pengembangan pembelajaran yang menyenangkan sehinga anak : memiliki kemampuan mengidentifikasi masalahnya sendiri, belajar dan memikirkan diri, membuat keputusan dan bertindak secara mandiri; memiliki kepekaan terhadap nilai-nilai kemanusian; memiliki stanina dan kesehatan yang memadai.

Untuk dapat mewujudkan kedua hal tersebut makaperlu pengembangan kerjasam antara sekolah, keluarga dan masyarakat. Salah satu bentuk kerjasama yang telah direkomendasikan oleh dewan Nasional untuk Belajar Sepanjang Hayat adalah pemanfaat sumber daya masnusia. Anggota masyarakat yang memiliki keahlian tertentu, tanpa harus memiliki ijazah guru, dapat menjadi pengajar di sekolah secara paruh waktu.

\subsubsection{Belajar Sepanjang Hayat di Hongkong (Oleh: Grace O.M.Lee)}

Pemunculan konsep pendidikan berkelanjutan sudah terjadi pada tahun 1950 an, dengan sasaran anggota masyarakat di atas usia sekolah. Pada saat itu seksi pendidikan orang dewasa pada kementrian pendidikan menyelenggarakan program remdial bagi orang dewasa, sementara itu universitas Hongkong menawarkan 12 macam kursus. Kemudian satu dekade kemudian disusul oleh universitas Cina Hongkong menawarkan program bagi golongan intelektual, dan universitas Cartas Hongkong juga menyelengarakan kegiatan untuk program keagamaan.

Perhatian pemerintah terhadap belajar sepanjang hayat telah dimulai pada tahun 1975 sejak dikeluarkanya dokumen putih. Dalam dokumen itu dinyatakan bahwa secara prinsip pemberian kesempatan belajar pada orang dewasa harus dihargai. Pemerintah mendorong pihak swasta untuk menyelenggrakan kegiatan belajar bagi orang dewasa, akan tetapi tidak memberikan subsidi. Kemudian pada tahun 1975 pada saat ada proteksi ekspor tekstil, pemerintah membentuk satu Komite untuk memberi respon terhadap hal tersebut. Komite ini menaruh perhatian terhadap kemungkinan pendidikan dan pelatihan bagi para pekerja. Maka mereka merekomendasikan bahwa pemerintah perlu mengkaji tentang tujuan dan strategi untuk mengkoordinasi, membuka univesitas terbuka. Pemerintah mengakui bahwa memang tidak ada sistem yang mengkoordinasi penyelenggaraan pendidikan orang dewasa.

Perkembangan terus berlangsung. Pemerintah mendirikan pusat pendidikan berkelanjutan dan pendidikan profesioanl di Politeknik Hongkong, pada tahun 1988, dan tiga tahun kemudian disusul dengan pendirian pendidikan profesioanl dan sekolah berkelanjutan di City Universitas Hongkong. Di samping itu, pada tahun 1989 pemerintah juga mendirikan institut belajar terbuka (Open Learning Institute). Berbeda dengan dua lembaga yang lain, OLI menyelenggarakan program gelar tanpa ada persyaratan pendidikan sebelumnya. Semenjak saat itu banyak anggota masyarakat yang mengikuti program belajar sepanjang hayat.

Peserta program belajar sepanjang hayat pada umumnya memiliki karakteristik yang hampir sama. Mereka adalah para pekerja dewasa, laki-laki dan perempuan, yang menginginkan peningkatan keterampilan dan kemampuannya untuk menyesuaikan diri dengan perkembangan yang ada. Sementara itu bagi para remaja dan penganggur kegiatan tersebut dipandang sebagai investasi memasuki lapangan kerja.

Perkembangan yang sangat menggembirakan tersebut kurang diimbangi dengan penanganan yang memadai oleh pemerintah. 
Tidak adanya kontrol kualitas, kurangnya koordinasi, tidak ada subsidi adalah beberapa contoh dari lemahnya penanganan tersebut. Oleh karenaitu, mengingat begitu penting peran belajar sepanjang hayat dalam mendukung kehidupan ekonomi maka pemerintah sebaiknya melakukan penanganan secara tepat. Penetapan standar kompetensi, subsidi bagi penduduk miskin, koordinasi bersistem, penyediaan program bagi semua kebutuhan belajar masyarakat adalah beberapa hal yang harus mendapat perhatian.

\subsubsection{Belajar Sepanjang Hayat dan Identitas Budaya: Penduduk Asli Canada (Brian Rice dan John Steckely).}

Setiap masyarakat berusaha untuk mempertahankan kebudayaannya, tidak terkecuali penduduk asli di Canada. Proses pelestarian budaya tersebut dilakukan melalui belajar. Dalam masyarakat penduduk asli Canada, proses belajar tersebut dilakukan melalui dua cara, yaitu: a). Ceritera, b). Upacara ritual.

Kedua proses belajar yang berlangsung secara alami, dalam konteks budaya dan sepanjang hayat. Proses bercerita, tidak sekedar penyampaian informasi dari orang tua kepada anggota masyarakat. Proses tersebut terikat dan melekat dan tidak terlepas dengan konteks kehidupan secara menyeluruh. Mereka menyampaikan kebudayaan secara utuh, melalui percakapan yang menyenangkan. Upaya-upaya pengembangan kehidupam masyarakat asli dengan cara mencabut dari akar budayanya tidak akan pernah berhasil, justru akan memusnahkan. Sekedar sebagai contoh, sekolah Residensial yang dilakukan oleh pemerintah.

Implikasi yang dapat diambil adalah proses belajar tradisional yang dilakukan oleh penduduk asli perlu dihargai dan didukung. Mereka pada dasarnya sudah menerapkan prinsip belajar sepanjang hayat, dengan tidak memisahkan antara pengembangan keterampilan, pengetahuan dan kemampuan lainnya. Dalam proses belajar semuanya dilakukan secara terpadu. Dan yang lebih penting lagi, bahwa mereka telah membuktikan dapat hidup dalam kehidupan modern dalam konteks budaya mereka dan budaya dominan. Barangkali yang perlu kita pikirkan kembali dalam " makna hidup modern ".

\subsection{Permasalahan yang Perlu Diangkat dari Pemikiran Tokoh Pendidikan dalam Buku Lifelong Learning: Policies, Practices, And Programs}

Jika dilihat dari sudut pemaparan isi, ke 5 tulisan pemikiran tokoh pendidikan dalam buku lifelong learning: policies, practices, and programs tersebut dapat diklasifikasi menjadi tiga, yaitu deskriptif, interpretatif dan spekulatif. Deskriptif, yaitu menggambarkan fakta yang terjadi tanpa berupaya melakukan interpretasi atau penilaian. Interpretatif penulis berusaha menginterpretasikan suatu realitas atau teori. Dan spekulatif nampak bila penulis berusaha mengajukan suatu pemikiran untuk pemecahan masalah.

Pada umumnya tulisan dalam buku ini termasuk kategori deskriptif. Dalam deskripsinya, para penulis berusaha menggambarkan realitas pendidikan/belajar sepanjang hayat yang ada di masing-masing negara penulis. Dalam penggambaran ini, sebagian penulis berusaha menempatkan belajar sepanjang hayat dalam konteks sosio kultutral masyarakatnya, sebagian yang lain hanya sekedar menyampaikannya secara faktual tanpa berusaha melakukan evaluasi secara mendalam atau interpretasi. Kelompok tulisan yang pertama ini mampu memberikan makna belajar sepanjang hayat secara mendalam dan komprehensif.

Perkembangan belajar sepanjang hayat tidak terlepas dari perkembangan masyarakat. Oleh karena itu untuk memahami dinamika belajar sepanjang hayat harus diletakkan dalam 
konteks sosio-kultural-ekonomi-politik dan demograif. Di lihat dari segi sosio-ekonomi, secara kasar negara anggota APEC dapat kita klasifikasi menjadi 3, yaitu negara maju (Kanada), negara maju baru (Hongkong), dan negara sedang berkembang (Indonesia, Phlipina, Thailan tidak dibahas dalam tulisan ini karena tidak termasuk pada bagian 11-15 buku ini).

Ketiga kelompok negara tersebut memiliki dinamika perkembangan yang berbeda. Secara historis negara-negara maju tidak pernah menjadi jajahan (kecuali Asutralia, itupun dijajah oleh dirinya sendiri). Hal ini berpengaruh terhadap perkembangan sosiol ekonomi masyarakatnya. Kelompok negara ini kehidupan sosial ekonomi sangat dinamis, dan stabil. Struktur sosial masyarakat dan ekonominya sudah mapan. Pada saat ini mereka tinggal mempertahankan dan meningkatkan superioritas perkembangannya dan menikmati hasil.

Berkenaan dengan perkembangan tersebut, program belajar sepanjang hayat yang dilaksanakan di masing-masing negara anggota OPEC berbeda. Di negara maju, program yang banyak berkembang adalah program untuk pemenuhan kebutuhan pengembangan diri, seperti pengisian waktu luang, hobi, pengembangan keterampilan.

Di negara maju baru, program belajarnya lebih tertuju pada peningkatan dan pengembangan keterampilan teknologi tinggi. Sementara itu di negara sedang berkembang dikembangkan berorientasi pada peningkatan keterampilan teknologi menengah dan pengembangan sosial. walaupun berbeda, namun jika dicermati program tersebut ada kesamaanya, yaitu lebih didorong oleh kebutuhan ekonomi (economy driven).

Di negara maju dan negara maju baru, motivasi belajar masyarakat sudah berkembang baik, sehingga mereka dapat melakukan proses belajar secara mandiri. Sedangkan di masyarakat sedang berkembang, motivasi belajar mandiri masih belum berkembang secara merata.

Terlepas dari perbedaan yang ada, negaranegaraAPEC memiliki visi, dan komitmen yang sama. Mereka berupaya untuk mewujudkan belajar sepanjang hayat. Hal ini dapat dilihat dari kebijakan yang ditempuh. Walaupun dengan kondisi yang berbeda, semua negara berupaya untuk mewujudkan pendidikan yang demokratis, terbuka, untuk memenuhi kebutuhan belajar bagi siapa saja, kapan saja dan dimana saja.

Namun beberapa penulis, secara interpretatif, melihat bahwa kebijakan atau program belajar sepanjang hayat belum memadai mengingat tantangan ke depan yang semakin kompleks. Brian Rice dan John Steckely, melihat bahwa proses belajar yang tidak kontekstual justru akan menghilangkan eksistensi masyarakat itu sendiri. Yukiko Sawono melihat bahwa pengurangan hari sekolah tidak efektif untuk mewujudkan meningkatkan peran keluarga dalam pendidikan anak.

\subsection{Isu-Isu Global yang Muncul dari Pemikiran Tokoh Pendidikan dalam Buku Lifelong Learning: Policies, Practices, And Programs}

Pendidikan sepanjang hayat meliputi pendidikan sebagai program dan pendidikan sebagai proses. Sebagai program maka bentuk kegiatannya antara lain meliputi Pendidikan Informal, Pendidikan Formal dan Pendidikan Non formal. Kegiatan pendidikan sebagai proses dicirikan dengan adanya seperangkat kegiatan penggorganisasian kegiatan pembelajaran. Pendidikan sepanjang hayat mengacu kepada adanya serangkaian faktor ektrinsik yang akan mendorong sesorang untuk dapat atau mau belajar.

Belajar sepanjang hayat adalah suatu kegiatan yang dilakukan oleh seseorang sepanjang rentang kehidupannya, dikarenakan adanya kebutuhan untuk meningkatkan kualitas 
dirinya dan kebutuhan ini bersifat intrinsik, karena bergantung kepada motivasi dan kemampuan belajar individu tersebut.

Tiga terminologi utama yang mendasari konsep pendidikan sepanjang hayat adalah 'hidup atau kehidupan,' 'sepanjang hidup (sepanjang hayat)' dan 'pendidikan'. Arti yang terkandung dalam setiap terminologi ini, dan interpretasi yang diberikan kepadanya secara luas menentukan cakupan dan pengertian pendidikan sumur hidup atau sepanjang hayat. Pendidikan tidak berakhir pada saat berakhirnya pendidikan sekolah, tetapi dia merupakan proses sepanjang hayat. Pendidikan sepanjang hayat terjadi selama keseluruhan kurun kehidupan individu.

Pendidikan sepanjang hayat merupakan gagasan yang universal, terutama setelah ditegaskan oleh International Commision on the Development of Education (ICED), melalui tulisan Edgar Faure dkk. yang berjudul "Learning To Be : The World of Education to Day and Tomorrow”. (1972). Konsep pendidikan sepanjang hayat memandang pendidikan sebagai satu sistem yang menyeluruh, yang di dalamnya terkandung prinsip-prinsip pengorganisasian untuk pengembangan pendidikan.

Di abad XXI, pendidikan sudah semakin beragam, tugas-tugas dan bentuk-bentuknya melingkupi pengetahuan hidup tentang dunia, tentang manusia-manusia lain, dan tentang diri mereka sendiri, dengan dilandasi empat pilar pendidikan, yaitu : belajar mengetahui (learning to know), belajar berbuat (learning to do), belajar hidup bersama - belajar hidup dengan orang lain (learning to live together), dan belajar menjadi seseorang (learning to be).

Pembelajaran merupakan proses yang berlangsung seumur hidup, yaitu pembelajaran sejak lahir hingga akhir hayat yang diselenggarakan secara terbuka dan multimakna. Pembelajaran sepanjang hayat berlangsung secara terbuka melalui jalur formal, nonformal, dan informal yang dapat diakses oleh peserta didik setiap saat tidak dibatasi oleh usia, tempat, dan waktu. Pembelajaran dengan sistem terbuka diselenggarakan dengan fleksibilitas pilihan dan waktu penyelesaian program lintas satuan dan jalur pendidikan (multi entry-multi exit system).

\subsection{Implementasi Pemikiran Tokoh Pendidikan dalam Buku Lifelong Learning: Policies, Practices, And Programs untuk Meningkatkan Mutu Pendidikan di Indonesia}

Perwujudan belajar sepanjang hayat di Indonesia telah dijamin dalam undang-undang. Hal tersebut terdapat pada pasal 5 UU no 20 tahun 2003 tentang Sistem Pendidikan Nasional. Pada pasal tersebut disebutkan bahwa pendidikan diselenggarakan secara demokratis dan berkeadilan serta tidak diskriminatif dengan menjunjung tinggi hak azasi manusia, nilai keagamaan dan nilai kultural dan kemajemukan bangsa (ayat 1), pendidikan diselenggarakan sebagai satu kesatuan yang sistemik dengan sistem terbuka dan multimakna (ayat 2), pendidikan diselenggarakan sebagai suatu proses pembudayaan dan pemberdayaan peserta didik yang berlangsung sepanjang hayat (pasal 3).

Berdasarkan pada undang-undang dan beberapa pemikiran yang telah diuraikan di atas, dipandang perlu untuk mengajukan beberapa saran:

1. Orientasi dan program belajar sebaiknya berdasar dan mencakup dimensi sosiokultural. Program-program pengembangan kehidupan sosial hendaknya terus diupayakan secara berimbang.

2. Perlu digali dan dikembangkan pola belajar asli masyarakat (indigenous).

3. Dalam kaitannya dengan akreditisi pengalaman belajar, sebaiknya segera dibuat aturan perundangannya mengingat hal tersebut telah dimuat dalam UU NO 20 tentang Sistem Pendidikan Nasional, pasal 28 ayat 2 yang menyebutkan bahwa 
hasil pendidikan informal diakui sama dengan pendidikan formal dan nonformal setelah peserta didik lulus ujian sesuai dengan standar nasional pendidikan nasional.

4. Mengingat beragamnya latar sosio-kultural masyarakat Indonesia, dan kecenderungan perkembangan pada masa depan maka akan lebih baik bila dikembangkan pola atau format, program belajar yang sesuai dengan karakteristik warga belajar dan tantangan yang dihadapi.

Pendidikan adalah Upaya untuk memberdayakan manusia menjadi menusia yang seutuhnya agar dapat mengaktualisasikan diri, memahami diri serta dapat menghidupi dirinya sendiri. Mencapai itu semua ada proses yang harus dilalui, dalam proses pendidikan terdapat pendidik dan yang dididik serta sarana yang mendukung proses pencapai tujuan pendidikan. AdapunTujuan pendidikan secara Umum dalam Pembukaan Undang-Undang Dasar 1945 yaitu mencerdaskan kehidupan Bangsa. Sedangkan menurut Undang-undang Republik Indonesia No. 20 Tahun 2003 tentang Sistem pendidikan nasional Bab I pasal 1 di nyatakan bahwa pendidikan adalah usaha sadar dan terencana untuk mewujudkan suasana belajar dan proses pembelajaran agar peserta didik secara aktif mengembangkan potensi dirinya untuk memiliki kekuatan spiritual keagaman, pengendalian diri, kepribadian, kecerdasan, akhlak mulia, serta ketrampilan yang diperlukan dirinya, masyarakat, bangsa dan negara.

Tujuan Pendidikan Nasional dapat diperoleh melalui pendidikan formal, informal dan non formal. Berdasarkan UU No. 20 Tahun 2003 tentang Sisdiknas penyelenggaraan pendidikan dapat diselenggarakan melalui jalur pendidikan formal dan non formal. Jalur pendidikan formal diselenggarakan di sekolah, sedangkan jalur pendidikan informal dan nonformal diselenggarakan di lingkungan keluarga dan masyarakat. Artinya manusia dapat belajar dirumah dan penyelenggaraan pendidikan dapat dilaksanakan di masyarakat.

\section{SIMPULAN}

Berdasarkan pemikiran tokoh pendidikan dalam buku lifelong learning: policies, practices, and programs yang diuraikan diatas telah menegaskan bahwa pendidikan informal dan nonformal hadir di masyarakat karena semakin meningkatnya kebutuhan masyarakat akan pendidikan nonformal sebagai pengganti, penambah dan pelengkap pendidikan formal serta dalam rangka mendukung pendidikan sepanjang hayat. Pendidikan informal dan nonformal berfungsi mengembangkan potensi peserta didik dengan penekanan pada penguasaan pengetahuan dan keterampilan fungsional serta pengembangan sikap dan kepribadian professional.

\section{DAFTAR PUSTAKA}

Ainsworth,. M. D. S.b Blchar. M. C.. Walthers, E. \& Wall, S. (I97B). Patterns of Attacbment: A Psychological Study of the Strange Situation, Hillsdale. NJ: Erlbaum.

Advisory Council for Adult and Continuing Eduction( 1983). Continuing Education from Policies to Practice In M Tight (Ed). Qpprortunities for adult Education. Kent: Biddles Limited.

Association for the Study of Confucianism, Shanxi Province. (Ed.).(1988) A Compendium of Assays on the Study of Confucian thought. Taiyuan. Shanxi, China: Shanxi Renmin Chubanshe

Ball,C. (1993). Lifelong Learningand The School Curriculum. Paris: OECD/CERI

Bedcr.H.W(1981). Adult Education Should not Require Support from Learner Fees. .ln B. 
W Kreitlon (Ed). Examining Controversies in Continuing Education. San Francisco: Jossey-Bass.

Campbell, D. (1992). Parents and Schools Working for Student Succes. NASSP Bulletin 1.9

Chapman,J.D. \& Aspin,D.N. (in press). The School, The Community and Lifelong Learning, London: Cassell.

Chukyoshin. (1996). First Report of 15th Session of the Central Council for Education: A tnodel for tlft nation's Education in the 2 1st Century - Zest for Living and Peace of Mind. (Translation). Tokyo: Monbusho

Delors,J. (1996). Learning: The Treasure Within. Paris: UNESCO

Goldthorpe,J.H, Liecywcltyn, C.M. Payne, C. (1980). Social Mobility and Class Struc-ture in Modern Britain. Oxford: Clarendon Press.

Kimura, L.L. \& 'Aha Punana Leo. (1987). The Hawailan Language and its Revitalization. In F Ahcnakcw \& S. Fredeen (Eds), Our Languages, our
Survival: Proceedings of the Seventh Native American Languages Issues ( $p p$. Il7-l23). Saskatoon: Saskatchewan Indian Languages Institute.

Monbusho. (1996). Japanese Government Policies in Eduction, Science and Culture 1996: Tasks and \& Prospects for a Lifelong learning Society: (Translation). Tokyo: Author.

Morin. R., \& Balz D. (1996, January' 28). Americans Losing trust in each oibcr and institutions, Washington Post. A1,A6 \& A7.

Watt.Y H.W. (1994). Motivation of Adult Learnes:Astudy of Student in the Open Learning Institue of Hong Kong, With Policy Implications. Unpublished Mas-ter's Thesis. City Universiiy of Hong Kong. Hong Kong.

Ycc.A. H. (1989) Cross-cultural Perspectives on Higher Education in East Asia: Psychological effects upon Asian students. Journal nf Multilingual and Multicultural Development, 10 (3), 213232 